\title{
Two Time Periods of Hippocampal mRNA Synthesis Are Required for Memory Consolidation of Fear-Motivated Learning
}

\author{
Lionel Muller Igaz,, ${ }^{1}$ Monica R. M. Vianna, ${ }^{3}$ Jorge H. Medina, ${ }^{1,2}$ and Ivan Izquierdo ${ }^{3}$ \\ 1/nstituto de Biologia Celular y Neurociencias and 2Departamento de Fisiologia, Facultad de Medicina, Universidad de \\ Buenos Aires, 1121 Buenos Aires, Argentina, and ${ }^{3}$ Centro de Memoria, Departamento de Bioquimica, Instituto de \\ Biociencias, Universidade Federal de Rio Grande de Sul, 90035-003, Porto Alegre, Brazil
}

Information storage in the brain is a temporally graded process involving different memory types or phases. It has been assumed for over a century that one or more short-term memory (STM) processes are involved in processing new information while long-term memory (LTM) is being formed. It has been repeatedly reported that LTM requires de novo RNA synthesis around the time of training. Here we show that LTM formation of a one-trial inhibitory avoidance training in rats, a hippocampaldependent form of contextual fear conditioning, depends on two consolidation periods requiring synthesis of new mRNAs. By injecting the RNA polymerase II inhibitors 5,6-dichloro-1- $\beta$ D-ribofuranosylbenzimidazole or $\alpha$-amanitin into the CA1 region of the dorsal hippocampus at various times before and after training, we found that hippocampal gene expression is critical in two time windows: around the time of training and 3-6 hr after training. Interestingly, these two periods of sensitivity to transcriptional inhibitors are similar to those observed using the protein synthesis inhibitor anisomycin. These findings underscore the parallel dependence of LTM formation of contextual fear on mRNA and protein synthesis in the hippocampus and suggest that the two time periods of anisomycin-induced amnesia depend at least in part on new mRNA synthesis.

Key words: long-term memory; gene expression; hippocampus; rat; contextual fear; transcriptional inhibitors
From mollusks to mammals, memory can be divided into at least two phases: a protein and RNA synthesis-independent phase that lasts minutes to 1-3 hr [short-term memory (STM)] and a protein and RNA synthesis-dependent phase that lasts several hours to days, weeks, or even longer [long-term memory (LTM)] (McGaugh 1966, 2000; Davis and Squire, 1984; Emptage and Carew, 1993; Izquierdo et al., 1998). Therefore, a definite property of LTM that distinguishes it from other types of memory is its sensitivity to inhibitors of protein synthesis. Earlier behavioral studies in different animal models of learning and memory demonstrated that LTM requires de novo protein synthesis around the time of training (Davis et al., 1965; Davis and Squire, 1984). There was no deficit in the retention of the learned behavior when the protein synthesis inhibitors were applied even 1 or $2 \mathrm{hr}$ after training. However, the seminal work of Grecksch and Matthies (1980) showing that LTM formation for a brightness discrimination task in rats exhibits two sensitive periods for anisomycin fueled the idea that more than one wave of protein synthesis is required for memory formation. More recently, a growing body of evidence confirmed the existence of at least two different time windows for the amnesic effect of protein synthesis inhibitors. For instance, it has been reported that there are two time periods sensitive to anisomycin for fear-motivated learning in chicks (Freeman et al., 1995) and rats (Bourtchuladze et al., 1998;

Received Dec. 28, 2001; revised April 5, 2002; accepted May 10, 2002.

This work was supported by research grants from the National Research Council of Brazil (CNPq) through the National Programme for Nuclei of Excellence (PRONEX), and National Research Council of Argentina, National Science Agency, and the Ministry of Health of Argentina. We thank Pedro Bekinschtein for helping with some experiments.

Correspondence should be addressed to Jorge H. Medina, Instituto de Biologia Celular y Neurociencias, Facultad de Medicina, Universidad de Buenos Aires, Paraguay 2155, piso 3, 1121 Buenos Aires, Argentina. E-mail: jmedina@fmed.uba.ar. Copyright (C) 2002 Society for Neuroscience $0270-6474 / 02 / 226781-\bullet \$ 15.00 / 0$
Quevedo et al., 1999): one around the time of training and the other 3-4 hr after training. Interestingly, two similar periods were found for the amnesic action of PKA inhibitors in mice (Bourtchuladze et al., 1998) and rats (Bernabeu et al., 1997; Vianna et al., 1999). In addition, two waves of protein and glycoprotein synthesis are necessary for the formation of LTM of a visual categorization learning (Tiunova et al., 1998).

In marked contrast, the information concerning the critical time periods of transcription for LTM formation is scarce and fragmentary, mainly because actinomycin, the most widely used mRNA synthesis inhibitor, is quite toxic (Neale et al., 1973). Most behavioral studies using mRNA synthesis inhibitors have emphasized the importance of a single time window sensitive to inhibitors of mRNA synthesis at or around the time of training (Brink et al., 1966; Agranoff et al., 1967; Squire and Barondes, 1970; Neale et al., 1973; Thut and Lindell, 1974; Wetzel et al., 1976; Pedreira et al., 1996). However, cellular and molecular studies have shown multiple waves of gene induction during long-term facilitation in Aplysia (Barzilai et al., 1989) and long-term potentiation in the rat hippocampus (Abraham et al., 1993), two cellular models of learning and memory. In addition, it was shown that after an inhibitory avoidance training there were two periods of increased phosphorylation of the transcription factor cAMP response element-binding protein (CREB) in the CA1 region (Bernabeu et al., 1997). Nevertheless, these studies left open the question of whether there is only one or more than one time period of gene expression during LTM formation.

Therefore, to determine whether LTM requires a single wave or multiple waves sensitive to mRNA synthesis inhibition, we studied the effects before and after training of intrahippocampal infusion of two structurally and mechanistically different inhibitors of transcription on the retention of a one-trial inhibitory (passive) avoidance, a form of contextual fear conditioning. So 
far, this task has been the most studied in terms of the formal biochemical requirements in the hippocampus for memory formation (Izquierdo and Medina, 1997; Taubenfeld et al., 1999; McGaugh, 2000).

\section{MATERIALS AND METHODS}

Subjects. Male adult Wistar rats (age, 2.5 months old; weight, 220-250 $\mathrm{gm}$ ) from our own breeding colony were used. The animals were housed in plastic cages, five to a cage, with water and food ad libitum, under a $12 \mathrm{hr}$ light/dark cycle (lights on at 7:00 A.M.) at a constant temperature of $23^{\circ} \mathrm{C}$.

Surgery. Rats were implanted under deep thionembutal anesthesia with 30 ga guide cannulas in the dorsal CA1 region of the hippocampus at coordinates anterior -4.3 , lateral \pm 4.0 , and ventral 3.4 of the atlas by Paxinos and Watson (1986). The cannulas were fixed to the skull with dental acrylic (Bernabeu et al., 1997; Szapiro et al., 2000).

Inhibitory avoidance training and testing. After recovery from surgery, the animals were trained in inhibitory avoidance as described (Bernabeu et al., 1997; Barros et al., 2000; Walz et al., 2000). Briefly, the apparatus was a $50 \times 25 \times 25 \mathrm{~cm}$ acrylic box with a grid made of a series of 1-mm-caliber bronze bars spaced $1 \mathrm{~cm}$ apart. The left end of the floor was covered by a $7-\mathrm{cm}$-wide, $2.5-\mathrm{cm}$-high wood platform. Animals were gently placed on the platform; when they stepped down onto the grid they received a $2 \mathrm{sec}, 0.5 \mathrm{~mA}$ scrambled foot shock. Rats were tested for retention at $1.5 \mathrm{hr}(\mathrm{STM})$ and $24 \mathrm{hr}$ (LTM) after training. In the test sessions the foot shock was omitted; i.e., the conditioned stimulus (the apparatus) was not followed by the unconditioned stimulus (electric shock).

Open field and elevated plus maze tests were performed as described previously (Mesches et al., 1996; Wolfman et al., 1996; Izquierdo and Medina, 1997).

Drug infusion procedures. Cannulated rats received $15 \mathrm{~min}$ before training or immediately, 1, 2, 3, 4.5, 6, 7.5, or $9 \mathrm{hr}$ after training a bilateral inf usion of saline, DMSO, $\alpha$-amanitin (25 pg per side; Sigma, St. Louis, MO), and anisomycin ( $80 \mu \mathrm{g}$ per side, Sigma) dissolved in saline, or 5,6-dichloro-1- $\beta$-D-ribof uranosylbenzimidazole (DRB) (1.6 or $8 \mathrm{ng}$ per side; Sigma) dissolved in DMSO. The doses used for this studies were based on previous work in vivo, in hippocampal slices or brain homogenates, and the use of at least five times the $\mathrm{IC}_{50}$ of the compound (Montanaro et al., 1971; Thut and Lindell, 1974; Strocchi et al., 1977; Chodosh et al., 1989; Nguyen et al., 1994; Vianna et al., 2001). In all cases, infusions were bilateral and had a volume of $0.5 \mu \mathrm{l}$. The entire infusion procedure took $\sim 2 \mathrm{~min}$, including $45 \mathrm{sec}$ for the infusions themselves, first on one side and then on the other, and the handling. Histological examination of cannula placements was performed as described previously (Bernabeu et al., 1997; Izquierdo et al., 1998). Briefly, $24 \mathrm{hr}$ after the end of the behavioral procedures, $0.5 \mu \mathrm{l}$ of a solution of $4 \%$ methylene blue in saline was infused as indicated above into each implanted site. Animals were killed by decapitation $15 \mathrm{~min}$ later, and the brains were stored in formalin for histological localization of the inf usion sites. Inf usions spread with a radius of $<1.2 \mathrm{~mm}^{3}$, as described previously (Bernabeu et al., 1997; Vianna et al., 1999; Walz et al., 2000), and were found to be correct (i.e., within $1.5 \mathrm{~mm}^{3}$ of the intended site) in $95 \%$ of the animals (Fig. 1). Only the behavioral data from animals with the cannula located in the intended site were included in the final analysis.

Total RNA extraction and RT-PCR. Total RNA was isolated from the drug infusion area in the hippocampal region of trained animals, using a single-step method based on guanidine isothiocyanate-phenolchloroform extraction and TRIzol reagent (Invitrogen, Rockville, MD) (Chomczynski and Sacchi, 1987). Briefly, tissues were homogenized in 1 $\mathrm{ml}$ of TRIzol solution. Then, the mixture was extracted with $200 \mu \mathrm{l}$ of chloroform and centrifuged at $12,000 \times g$. The aqueous phase was precipitated with $500 \mu \mathrm{l}$ of isopropanol, and the pellet was washed once with ethanol $70 \%$ and resuspended in $25 \mu \mathrm{l}$ of RNase free water. RNA concentration was determined by absorbance at $260 \mathrm{~nm}$, and its integrity was verified by electrophoresis on $1 \%$ denaturing agarose gels in the presence of formaldehyde. A $1 \mu \mathrm{g}$ amount of total RNA was reverse transcribed to synthesize single-strand cDNA. The cDNA synthesis was performed using the mixtures $(20 \mu \mathrm{l})$ containing $1 \mu \mathrm{l}$ of Moloney murine leukemia virus-RT (Promega, Madison, WI), $1 \mu \mathrm{l}$ of deoxynucleotide triphosphate (dNTP) mixture (each of $10 \mathrm{~mm}), 2 \mu \mathrm{l}$ of oligo-dT15 primer $(0.1 \mu \mathrm{g} / \mu \mathrm{l}), 1 \mu \mathrm{l}$ of RNAsin (Promega), $2 \mu \mathrm{l}$ of RNA sample solution, 4 $\mu \mathrm{l}$ of RT buffer, and $9 \mu \mathrm{l}$ of RNase-free $\mathrm{H}_{2} \mathrm{O}$. The reaction mixture was incubated for $2 \mathrm{hr}$ at $42^{\circ} \mathrm{C}, 5 \mathrm{~min}$ at $95^{\circ} \mathrm{C}$, and $5 \mathrm{~min}$ at $4^{\circ} \mathrm{C}$. Subsequently,

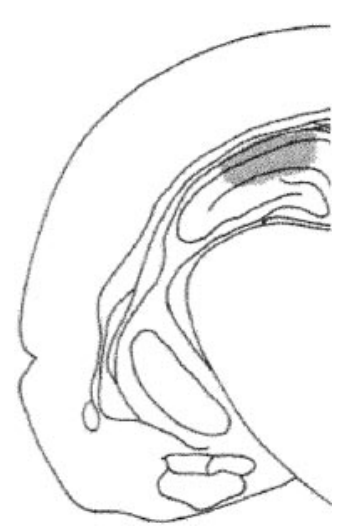

Figure 1. Schematic drawing of rat brain section at plane A -4.3 of the atlas of Paxinos and Watson (1986), showing in stippling, the extension of the area reached by the infusions in the dorsal hippocampus.

$1 \mu l$ of the RT reaction was subjected to PCR to amplify fragments using BDNF-specific or $\beta$-actin-specific primers: BDNF-sense primer $\left(5^{\prime}\right.$-TCA CAG TCC TGG AGA AAG TC-3'), BDNF-antisense primer (5'-ATG AAC CGC CAG CCA ATT CT-3') (Alonso et al., 2002); $\beta$-actin sense primer: (5'-ACC ACA GCT GAG AGG GAA ATC G-3'), $\beta$-actinantisense primer (5'- AGA GGT CTT TAC GGA TGT CAA CG-3') (Theas et al., 2001). The $50 \mu$ l PCR included $1 \mu$ l of previously synthesized cDNA, $1 \mu \mathrm{l}$ each of forward or reverse primers $(100 \mathrm{pmol} / \mu \mathrm{l}), 5 \mu \mathrm{l}$ of Taq polymerase Buffer (Promega), $1.2 \mathrm{~mm} \mathrm{MgCl}_{2}, 0.2 \mathrm{~mm}$ of each dNTP, $37.5 \mu \mathrm{l}$ of RNase-free $\mathrm{H}_{2} \mathrm{O}$, and $2.5 \mathrm{U}$ of Taq DNA polymerase (Promega). Negative controls without RNA and with non-retrotranscribed RNA were included in all the experiments. BDNF PCRs were performed in a UNO-Thermoblock thermal cycler (Biometra, Göttingen, Germany) as follows: 3 min denaturation at $95^{\circ} \mathrm{C}$, followed by $30-32$ cycles of $30 \mathrm{sec}$ at $95^{\circ} \mathrm{C}, 30 \mathrm{sec}$ at $60^{\circ} \mathrm{C}, 30 \mathrm{sec}$ at $72^{\circ} \mathrm{C}$, and a final extension of $5 \mathrm{~min}$ at $72^{\circ} \mathrm{C}$. Similar PCRs were performed for $\beta$-actin during 20-22 cycles with the same annealing temperature. The expected sizes for amplification products are $202 \mathrm{bp}$ for BDNF and $276 \mathrm{bp}$ for $\beta$-actin. The number of cycles performed was well within the exponential phase of the amplification process, and quantitative data between the two cycles were averaged for each sample and primer pair combination.

After PCR, the amplification products $(5 \mu \mathrm{l})$ were separated by $1.6 \%$ agarose gel electrophoresis containing $5 \mu \mathrm{g} / \mu \mathrm{l}$ ethidium bromide for $1 \mathrm{hr}$ at $7.5 \mathrm{~V} / \mathrm{cm}$. Bands were visualized by excitation at $316 \mathrm{~nm}$ and digitalized with a FOTO/Convertible Dual Transilluminator imaging system (Fotodyne, Hartland, WI), and the bands were quantified with the software ImageQuant version 5.1 for Windows NT (Molecular Dynamics, Sunnyvale, CA). BDNF gene expression was normalized to $\beta$-actin values.

Immunoblot assays. To investigate whether pretraining intrahippocampal infusion of DRB affects extracellular signal-related kinase (ERK) 1/2, calcium/calmodulin-dependent kinase II (CaMKII), and protein kinase C (PKC) activation, 3-mm-thick slices were taken immediately after training from the area in which the infusion cannulas were placed. Samples of homogenates (16 $\mu \mathrm{g}$ of protein) were subjected to SDSPAGE (10\% gels), and immunoblots were performed as described previously (Cammarota et al., 2000). Membranes were incubated with the following antibodies: anti-ERK1 and ERK2 (1:3000; Cell Signaling Technology, Beverly, MA), anti-activated ERK1 and ERK2 (1:4000; Cell Signaling Technology), anti-CaMKII (1:3000; Promega), anti-activated CaMKII (1:5000; Promega), and anti-activated PKC (1:2500; Cell Signaling Technology). Densitometric analysis of the films was performed by using an MCID Image Analysis System (version 5.02, Imaging Research Inc., St. Catharines, Ontario, Canada). Western blots were developed to be linear in the range used for densitometry. The filters were stripped out of the antibody before reprobing with antibodies for the total forms of the same kinases, and the ratio of the activated versus total form was calculated.

Data analysis. A ceiling of $180 \mathrm{sec}$ was imposed on test session values. This requires the use of nonparametric statistics: Kruskal-Wallis ANOVA followed by individual Mann-Whitney $U$ tests, two-tailed (Bernabeu et al., 1997; Barros et al., 2000; Szapiro et al., 2000; Walz et al., 2000). For open field and elevated plus maze tests, statistical analysis 
was performed using one-way ANOVA followed by the Duncan test. For RT-PCR and immunoblot experiments, statistical analysis was performed by one-way ANOVA using the Newman-Keuls test.

\section{RESULTS}

\section{Two time windows of DRB-induced amnesia for inhibitory avoidance training}

To investigate whether one phase or more than one phase of mRNA synthesis is necessary for LTM formation we used a one-trial step-down inhibitory avoidance training. This fearmotivated learning is a hippocampal-dependent task that is acquired in a single, brief training session (Winocur and Bindra, 1976; Thompson, 1977; Gold, 1986; Lorenzini et al., 1996; Izquierdo and Medina, 1997; Taubenfeld et al., 1999), which makes it ideal for investigating the role of time-dependent mechanisms initiated during memory processing without the interference from retrieval of the learned behavior that might occur in multitrial tasks (Izquierdo and Medina, 1997).

Given that the most widely used transcriptional inhibitor, actinomycin $\mathrm{D}$, irreversibly blocks transcription mediated by all three classes of RNA polymerases, causes cerebral damage, and impairs animal behavior when administered locally in the brain (Neale et al., 1973; Rainbow, 1979), and that LTM formation of inhibitory avoidance training is a hippocampal-dependent process (Izquierdo and Medina, 1997; Vianna et al., 2001), we decided to use the adenosine analog DRB infused into the CA1 region of the dorsal hippocampus. The advantages of using DRB as a transcriptional inhibitor include the reversibility of its effect and its ability to selectively inhibit RNA polymerase II (Tamm, 1977; Chodosh et al., 1989; Clement and Wilkinson, 2000). DRB $(100 \mu \mathrm{M})$ impaired long-term, but not short-term, enhancement after one-trial conditioning in Hermissenda (Crow et al., 1997). When applied to hippocampal slices, inhibition of $\left[{ }^{3} \mathrm{H}\right]$ uridine incorporation by DRB $(100 \mu \mathrm{M})$ reverses rapidly within 2-3 hr (Nguyen et al., 1994). Because incorporation experiments in vivo with radiolabeled precursors do not account for changes in precursor pool size as a result of behavioral training, among other drawbacks (Rainbow, 1979), we decided to measure the end-point effect of DRB on steady-state mRNA levels using semiquantitative RT-PCR. We assessed the amount of a short-lived transcript, BDNF, in region CA1 of the hippocampus of trained animals (Fig. $2 J)$. One hour after $1.6 \mathrm{ng}$ per side $(10 \mu \mathrm{M})$ DRB injection, BDNF mRNA levels decreased by $28 \%$ with respect to vehicleinfused controls, whereas $\beta$-actin mRNA levels remained unchanged. Normalized BDNF mRNA levels decreased by $35 \%$ with respect to vehicle-inf used controls.

Figure 2 shows the effects of before training $(-15 \mathrm{~min})$ or after training $(0,+1,+2,+3,+4.5,+6,+7.5$, or $+9 \mathrm{hr})$ infusions of DRB into the CA1 region of the dorsal hippocampus on retention of inhibitory avoidance response as measured $1.5 \mathrm{hr}$ (STM) or 24 hr (LTM) after training. There were no differences between groups in training performance in any group studied ( $p=0.12$; Kruskal-Wallis test). DRB (1.6 ng per side) infused bilaterally into the CA1 caused LTM deficits when given before training or $0 \mathrm{~min},+3,+4.5$, or $+6 \mathrm{hr}$ after training (Fig. $2 A, B, E-G$ ). No effects were seen when DRB was injected at $+1,+2,+7.5$, or +9 hr before training, indicating that DRB-induced amnesia is not attributable to a retrieval deficit or nonspecific effects of the drug. Similar results were obtained using a higher dose of DRB (8 ng per side, $50 \mu \mathrm{M}$ ), except that at $2 \mathrm{hr}$ after training the transcriptional inhibitor also caused an impairment of LTM (Fig. 2D). These findings indicate that there are two time windows of
DRB-induced amnesia for inhibitory avoidance training: one around the time of training and the other 3-6 hr later. No deficits were found in STM retention performance (Fig. 2), except for the group injected at -15 min (Fig. $2 A$ ).

Given that DRB inhibits casein kinase II, which has been reported to modulate NMDA currents (Lieberman and Mody, 1999), we decided to perform experiments to determine whether DRB could affect the phosphorylation (activation) of three major protein kinases downstream of NMDA receptors already known to be required in memory formation in the hippocampus (ERK1/2, CaMKII, and PKC). The infusion of DRB into the CA1 region of the dorsal hippocampus before training does not affect the activation of these three kinases immediately after training, as determined through immunoblot assays of the activated forms (ERK 1: vehicle $100 \pm 17 \%$, DRB $120 \pm 14 \%$; ERK 2: vehicle $100 \pm 42 \%$, DRB $149 \pm 30 \%$; CaMKII: vehicle $100 \pm$ $14 \%$, DRB $76 \pm 26 \%$; PKC: vehicle $100 \pm 17 \%$, DRB $113 \pm 11 \%$; $p>0.05 ; n=5-6)$.

Several nonspecific factors affecting sensory-motor and emotional processes can influence acquisition or retention performance of an inhibitory avoidance task (Mesches et al., 1996; Izquierdo and Medina, 1997). The bilateral intrahippocampal infusion of DRB 15 min before an open field or an elevated plus maze did not produce changes in locomotor activity, exploratory behavior, or the "anxiety state" of these animals (Fig. 3A,B) indicating that the impairing effect of the pretraining infusion of DRB on STM is not caused by gross behavioral alterations on training performance.

\section{Avoidance training exhibits identical time periods of sensitivity to $\alpha$-amanitin, a structurally and mechanistically distinct transcriptional inhibitor}

To further determine whether two waves of mRNA synthesis are required for LTM formation, we next examined the effects of the bilateral intrahippocampal infusion of $\alpha$-amanitin at the same time points shown in Figure 2. $\alpha$-Amanitin, like DRB, has been described as a specific inhibitor of RNA polymerase II (Lindell et al., 1970). It has been shown that $10-100 \mathrm{ng} / \mathrm{ml} \alpha$-amanitin inhibited by $80 \%$ RNA polymerase II in isolated rat brain nuclei (Montanaro et al., 1971); however, their mechanisms of action are different (Kedinger et al., 1970; de Mercoyrol et al., 1989; Clement and Wilkinson, 2000).

In early studies, it was shown that pretraining intracerebroventricular administration of high doses of $\alpha$-amanitin $(>500 \mathrm{ng} / \mathrm{ml})$ transiently inhibited mRNA synthesis and caused an impairment in LTM formation of fear-motivated learning tasks (Thut and Lindell, 1974; Strocchi et al., 1977). However, they did not answer the crucial question of at what time period(s) in memory formation gene expression is required. As shown in Figure 4, inhibitory avoidance training shows two time periods of sensitivity to $\alpha$-amanitin (50 ng/ml, $25 \mathrm{pg}$ per side): one around training $(-15$ and 0 min time points) and the other 3-6 hr after training. Because $\alpha$-amanitin had no effects on retention test performance when given $1,2,7.5$, or $9 \mathrm{hr}$ after training, $\alpha$-amanitin-induced amnesia is not caused by an impairment of memory retrieval. These findings together with those obtained using DRB (Fig. 2) indicate that memory consolidation for inhibitory avoidance requires at least two waves of gene expression in the hippocampus.

As it occurred in DRB-injected animals, the pretraining infusion of $\alpha$-amanitin also impaired STM retention. It is important to stress here that no alterations in locomotor activity, explor- 
A

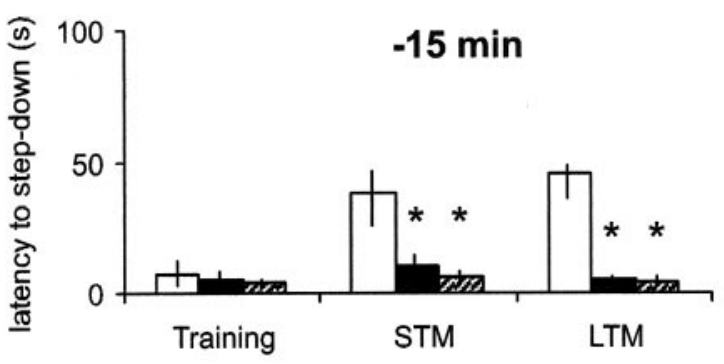

C

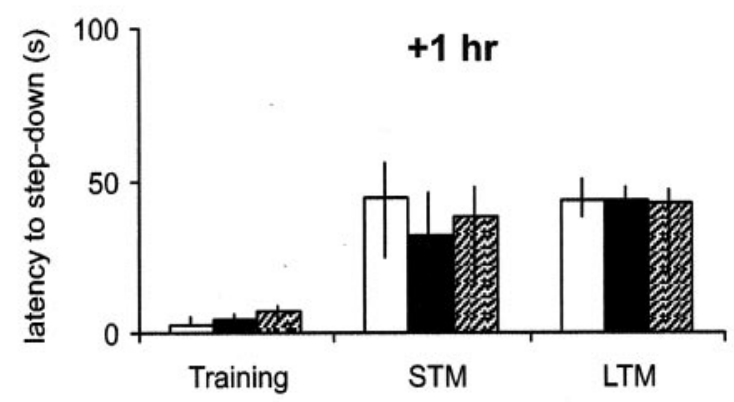

E

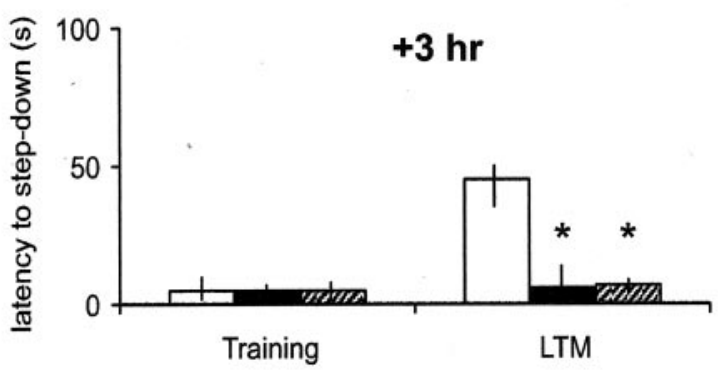

G

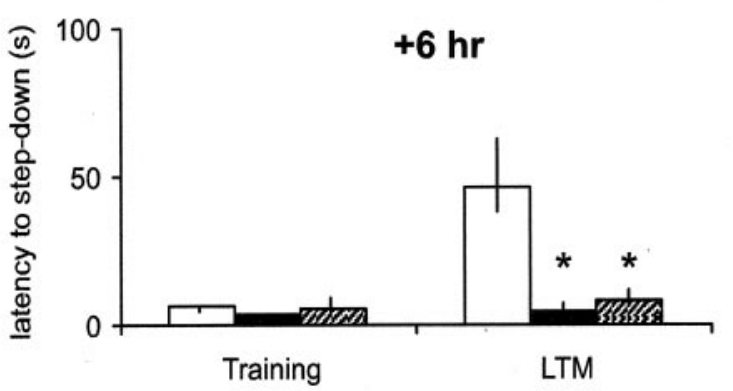

I

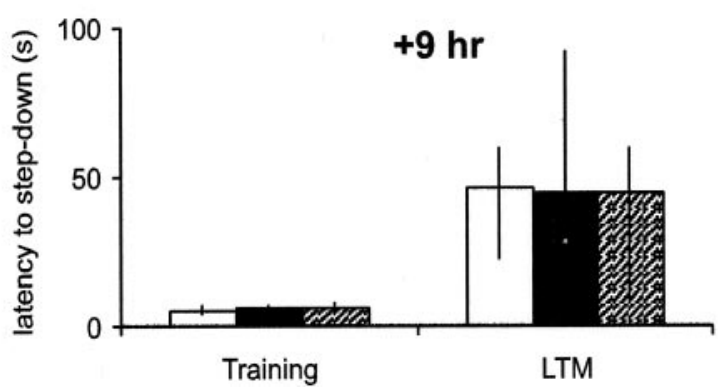

B

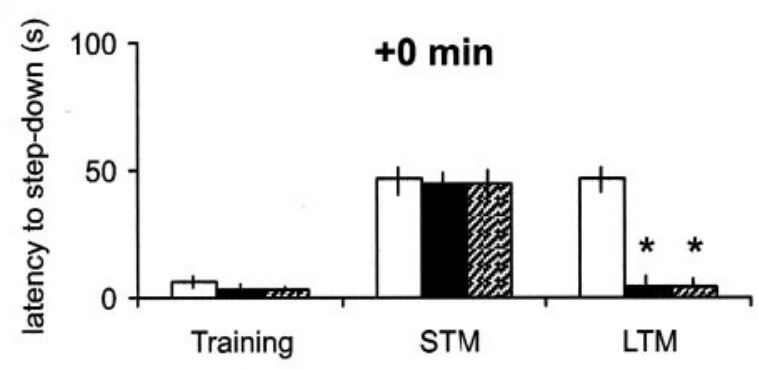

D

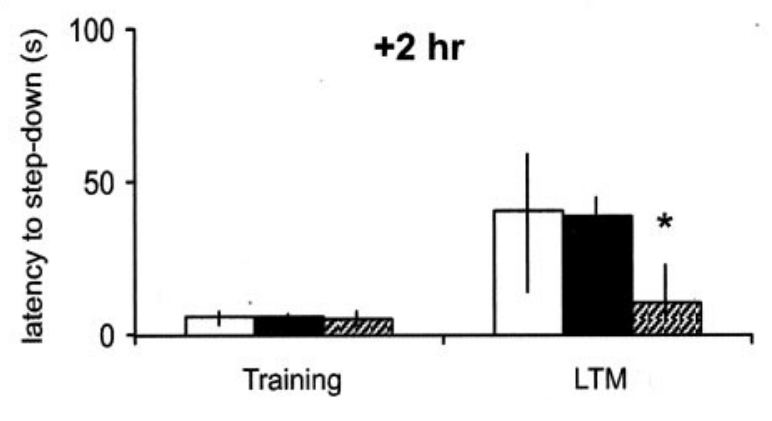

F

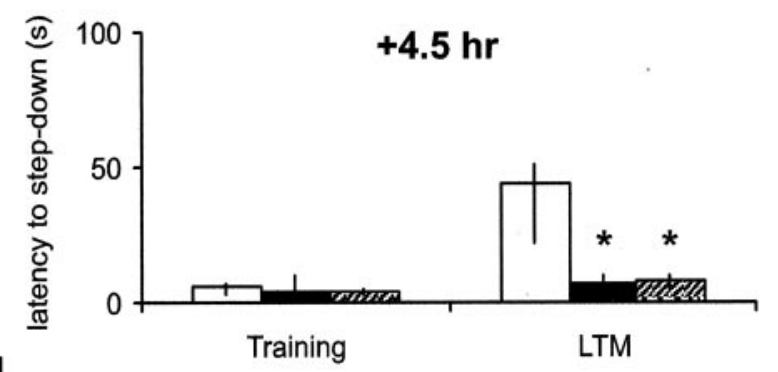

H

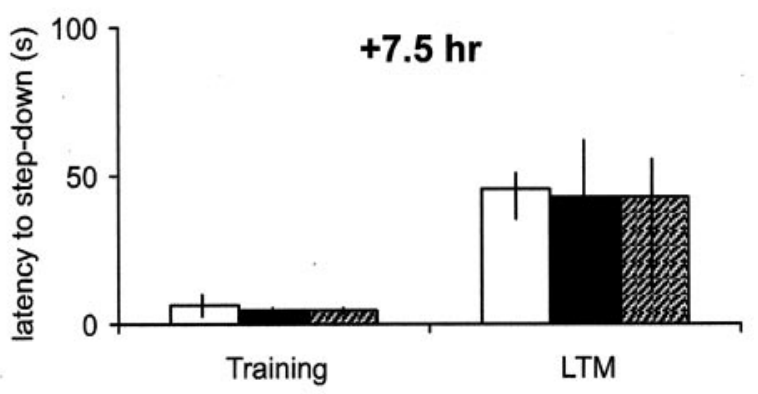

J

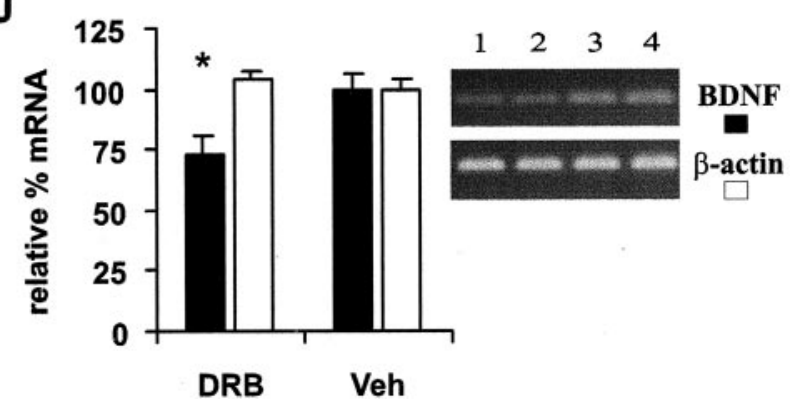

Figure 2. Two waves of mRNA synthesis in the hippocampus are required for long-term memory formation for one-trial inhibitory avoidance, a form of contextual fear conditioning. A-I, DRB $1.6 \mathrm{ng}$ per side (closed bars) or $8 \mathrm{ng}$ per side (hatched bars) or vehicle (open bars) were inf used into the CA1 region of the dorsal hippocampus at different times before or after training. Data are expressed as median (interquartile range) training and test sessions latencies (in seconds). Retention test session for STM was performed at $1.5 \mathrm{hr}$ after training, whereas that for LTM was performed $24 \mathrm{hr}$ after training. $n=9-11$ animals per group. ${ }^{*} p<0.001$ compared with saline-infused rats (Mann-Whitney $U$ test). $J$, Effect of DRB infusion on BDNF and $\beta$-actin mRNA steady-state levels. Semiquantitative RT-PCR was performed using mRNA extracted from the infusion area in the dorsal hippocampus 1 hr after DRB $1.6 \mathrm{ng}$ per side treatment (for details, see Materials and Methods). Left, Densitometric analysis of BDNF (closed bars) or $\beta$-actin (open bars) cDNA from DRB-infused, trained animals with respect to vehicle-infused, trained animals. Data are expressed as mean \pm SEM percentage of mean vehicle values (BDNF $19.0 \pm 1.1$ arbitrary units; $\beta$-actin $17.6 \pm 0.7$ arbitrary units); $n=5-7 ;{ }^{*} p<0.05$ with respect to vehicle group; Newman-Keuls test. Right, Representative RT-PCR for BDNF (top) and $\beta$-actin (bottom) mRNA. 1-2, DRB-infused, trained animals; 3-4, vehicle-infused, trained animals. 

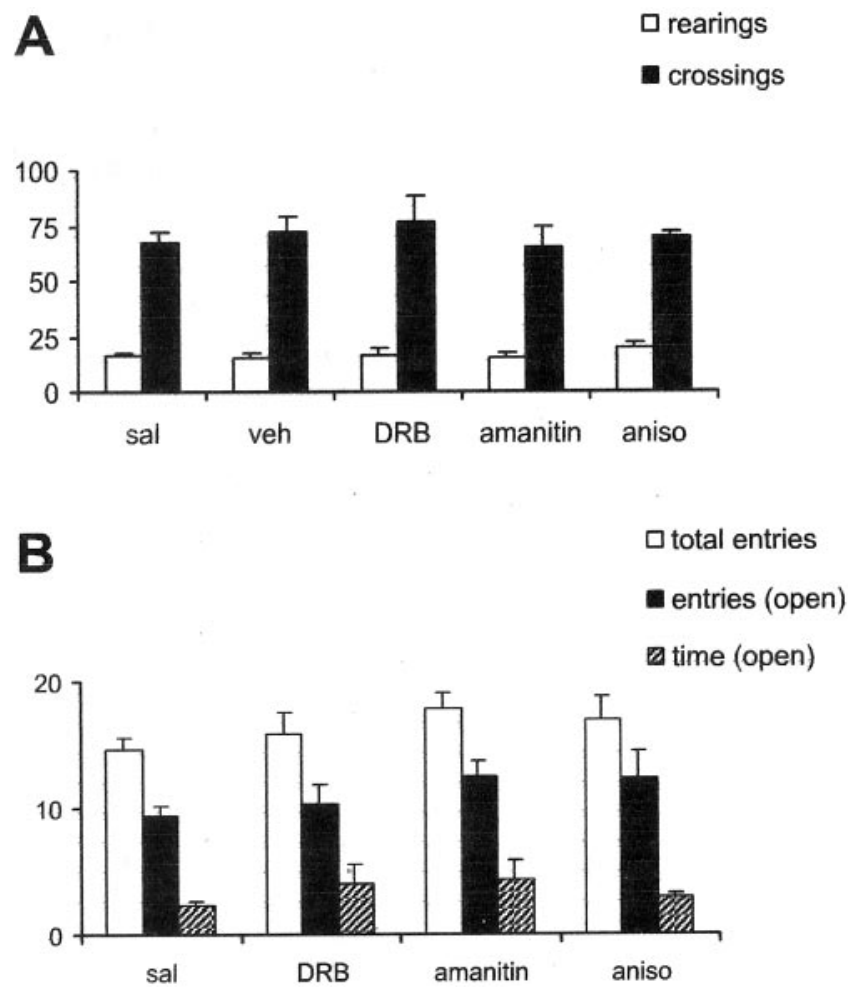

Figure 3. DRB (8 ng per side), $\alpha$-amanitin (25 pg per side), or anisomycin $(80 \mu \mathrm{g}$ per side) infusion produced no deficits in locomotion, exploration, and fear-related behaviors. $A$, Effects of intrahippocampal inf usion (15 min before training) of the drugs on the number of rearings (open bars) and crossings (closed bars) measured in the open field test (mean \pm SEM; $n=8$ per group). No differences were found in ANOVA followed by Duncan multiple comparison test. $B$, Here the animals were exposed to a 5 min elevated plus maze test: open bars, total arm entries; closed bars, open arm entries; hatched bars, time spent in the open arms (mean \pm SEM; $n=8-10$ animals per group). No significant differences were found in ANOVA followed by Duncan multiple comparison test.

atory behavior, or anxiety state of these animals were observed (Fig. 3A,B).

\section{Two time periods of sensitivity to anisomycin for contextual fear learning}

Confirming and extending previous findings (Quevedo et al., 1999), LTM but not STM formation of inhibitory avoidance task is dependent on two waves of protein synthesis (Fig. 5). The two time windows for the amnesic effects of intrahippocampal infusion of anisomycin ( $80 \mu \mathrm{g}$ per side) are quite similar to those observed using the two transcriptional inhibitors. However, anisomycin did not impair LTM formation when infused immediately after training (Fig. 5B).

Pretraining infusions of anisomycin appear not to produce nonspecific effects on training performance, because no changes in locomotor activity, exploratory behavior, or anxiety state were observed 15 min after anisomycin administration (Fig. 3A,B).

\section{DISCUSSION}

The present findings lead to a major conclusion. There are two time windows, one around training and the other 3-6 hr after, during which inhibitors of mRNA synthesis infused into CA1 produced amnesia for a one-trial inhibitory avoidance task, a form of contextual fear conditioning widely used in studies of the pharmacology and biochemistry of memory consolidation (Izqui- erdo and Medina, 1997; Taubenfeld et al., 1999, 2001; Izquierdo and McGaugh, 2000; McGaugh, 2000).

It is widely accepted that long-term memory consolidation is a time-dependent process that requires mRNA and protein synthesis (Agranoff et al., 1967; Squire and Barondes, 1970; Grecksch and Matthies, 1980; Davis and Squire, 1984; Freeman et al., 1995; Bourtchuladze et al., 1998; Milner et al., 1998; Quevedo et al., 1999; Kandel, 2001). Although there is now a growing body of evidence demonstrating that consolidation of LTM of different learning tasks in vertebrates has at least two time periods sensitive to anisomycin, only one time window of sensitivity to inhibitors of mRNA synthesis has been found so far (Agranoff et al., 1967; Squire and Barondes, 1970; Neale et al., 1973; Thut and Lindell, 1974; Wetzel et al., 1976; Pedreira et al., 1996). The two time windows for the amnesic effects of DRB and $\alpha$-amanitin observed in the present study parallel those found using anisomycin (Fig. 5) and are in accord with previous studies showing two critical periods of sensitivity to protein synthesis inhibitors (Grecksch and Matthies, 1980; Freeman et al., 1995; Bourtchuladze et al., 1998; Quevedo et al., 1999). On the basis of these findings and in agreement with previous interpretations of anisomycin-induced amnesia (Bourtchuladze et al., 1998; Quevedo et al., 1999), we suggest that the early time period (around training) is the phase during which transcription factors and immediate early genes are being expressed and the later time period (3-6 hr after training) is the phase during which structural genes are being expressed. Their protein products are involved in long-lasting synaptic remodeling required for LTM formation (Rose, 1995; Bailey et al., 1996; Kandel, 2001).

The present findings suggest that during the formation of contextual fear memory, the two protein synthesis-dependent phases in the hippocampus depend, at least in part, on new mRNAs synthesized as a consequence of transcriptional regulation. Given that the early protein synthesis phase parallels the mRNA synthesis wave (Figs. 2, 4, 5), the possibility exists that preexisting mRNAs locally translated in dendrites may participate in synaptic modifications involved in memory formation (Steward, 1997; Kandel, 2001; Krichevsky and Kosik, 2001). Alternatively, it was recently proposed that new protein synthesis occurs in response to need: it is required only to replenish proteins that have been used, post-translationally modified, translocated, and proteolitically cleaved (Routtenberg, 2001).

Unexpectedly, DRB and $\alpha$-amanitin impaired STM when given 15 min before training. It is generally accepted that STM, unlike LTM, is not dependent on either gene expression or protein synthesis (McGaugh, 2000; Kandel, 2001). There are two possible explanations for this discrepancy. First, both drugs may have nonspecific effects when given before training. However, they did not affect step-down latencies during training (Figs. 2, 4), and also they did not modify several behavioral parameters in two control experiments (Fig. 3). Despite this, we cannot fully rule out the possibility that both drugs could provoke subtle modifications in the acquisition process. In addition, the possibility exists that both drugs could block or affect other mediators of learning (kinases, protein synthesis). We discarded the possibility that protein synthesis inhibition is involved, because administration of anisomycin before training did not produce an impairment of STM (Fig. 5). Although $\alpha$-amanitin blocks transcription acting directly on RNA polymerase II (Kedinger et al., 1970; Lindell et al., 1970, de Mercoyrol et al., 1989), DRB is a transcriptional inhibitor via the blockade of casein kinase II (Zandomeni et al., 1986) and therefore could affect other signaling pathways involved in learning, 
A

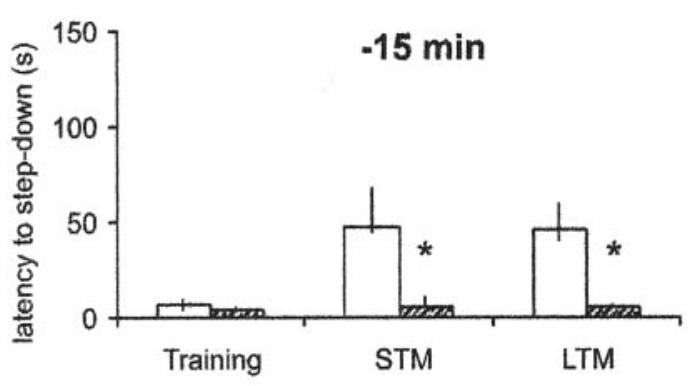

C

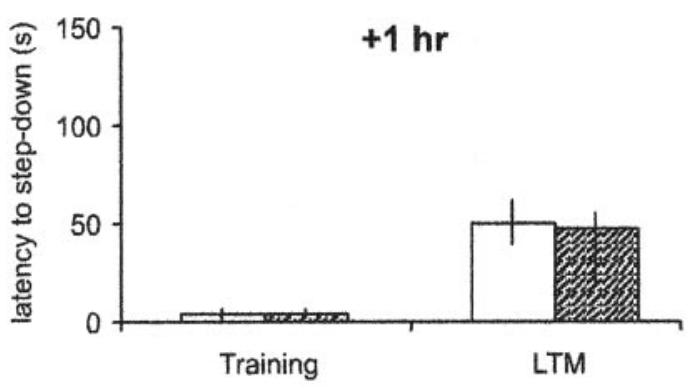

E

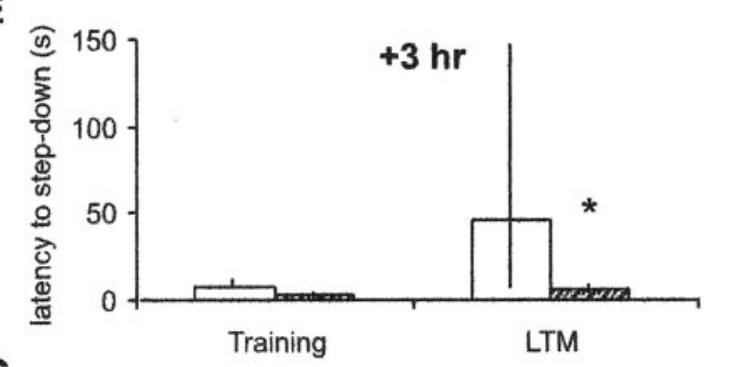

G

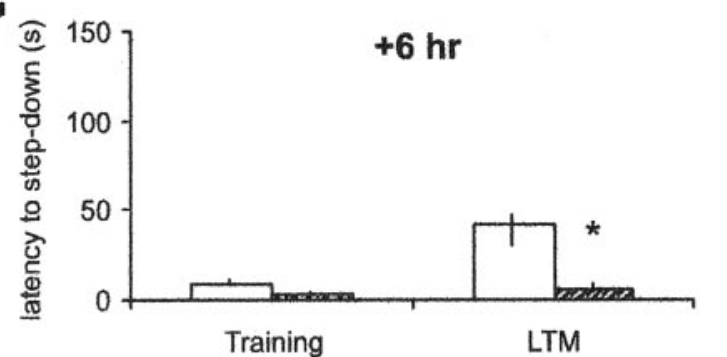

I
B

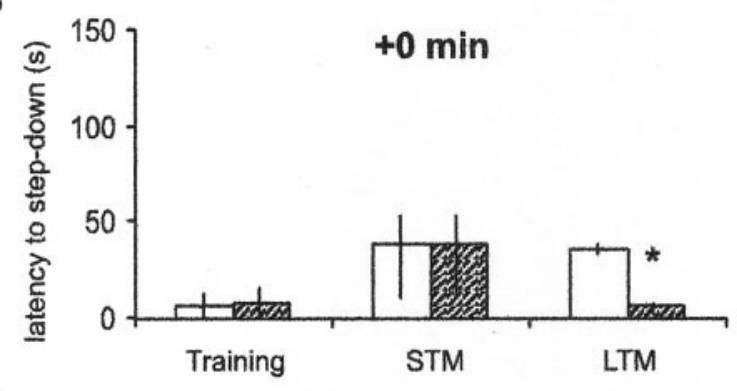

D

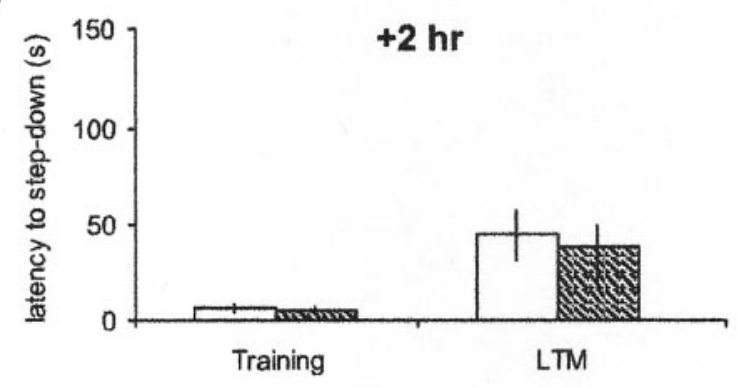

F

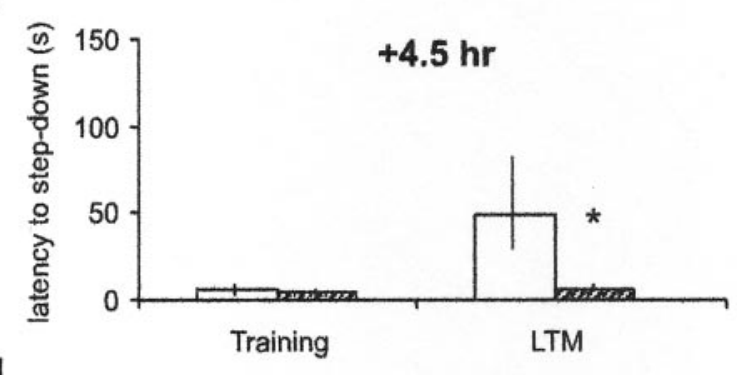

H

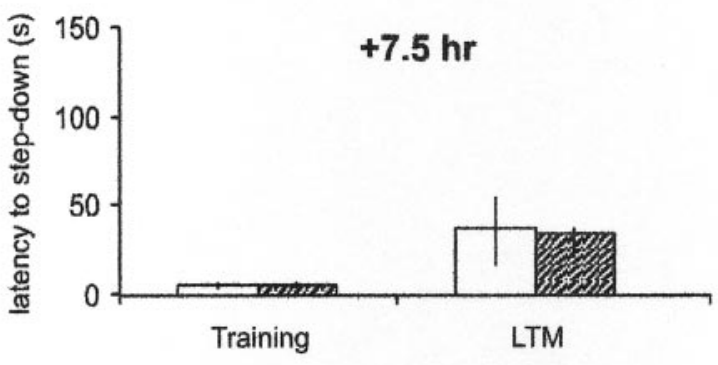

Figure 4. One-trial inhibitory avoidance shows identical time windows of sensitivity to a different transcriptional inhibitor, $\alpha$-amanitin. $A-I, \alpha$-Amanitin $25 \mathrm{pg}$ per side (hatched bars) or saline (open bars) was inf used into the CA1 region of the dorsal hippocampus at different times before or after training. Data are expressed as median (interquartile range) training and test sessions latencies (in seconds). Retention test session for STM was performed at $1.5 \mathrm{hr}$ after training, whereas that for LTM was performed $24 \mathrm{hr}$ after training. $n=9-11$ animals per group. ${ }^{*} p<0.001$ compared with saline-infused rats (Mann-Whitney $U$ test).

such as NMDA receptors (Lieberman and Mody, 1999). The inf usion of DRB into the CA1 region of the dorsal hippocampus does not affect the activation of CaMKII, ERK1/2, and PKC (see Results), three protein kinases involved in memory processing of the one-trial inhibitory avoidance task (Izquierdo and Medina 1997; Izquierdo and McGaugh, 2000; McGaugh, 2000). In addition, if DRB were affecting memory via NMDA receptors and protein kinases, it should produce similar effects on STM and 
A

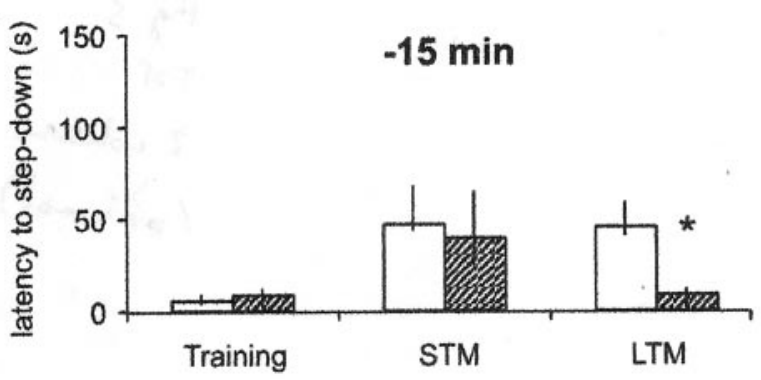

C

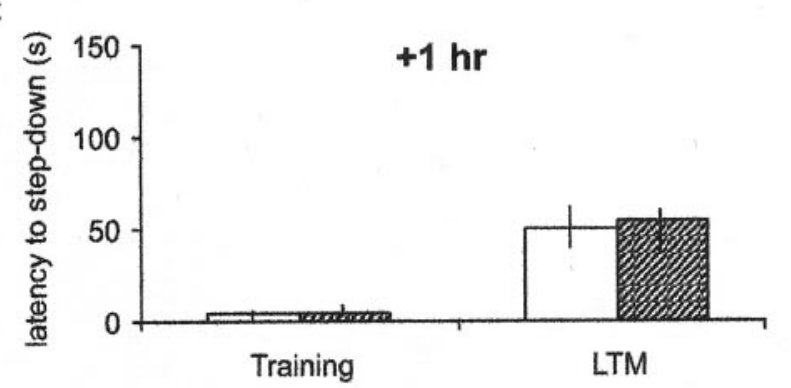

$E$

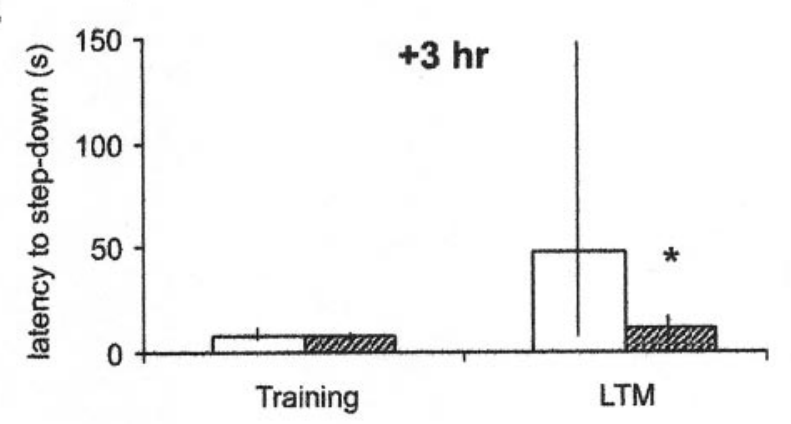

G

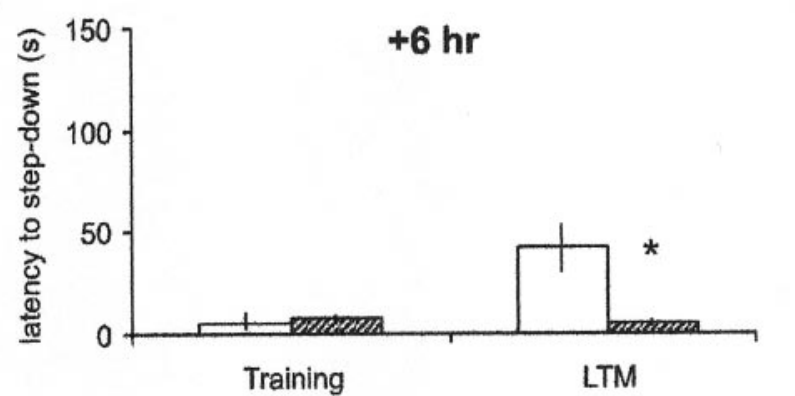

I

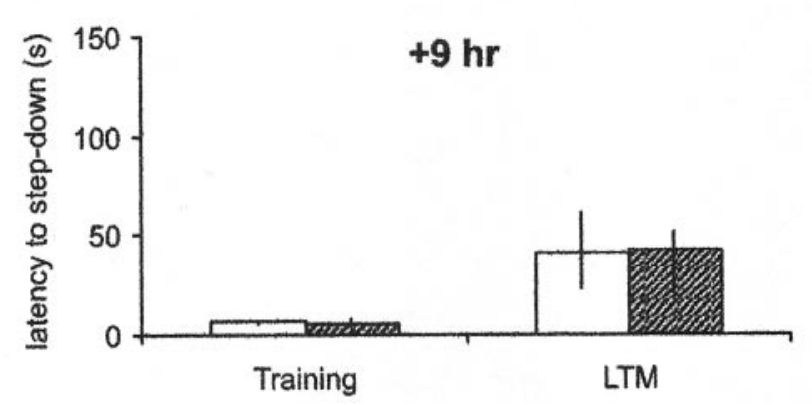

B

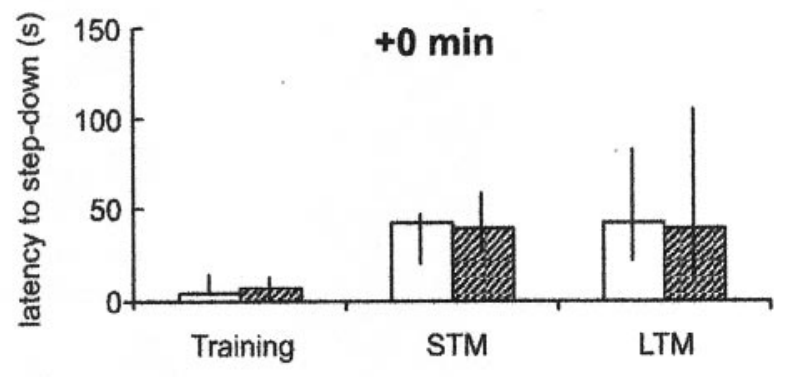

D

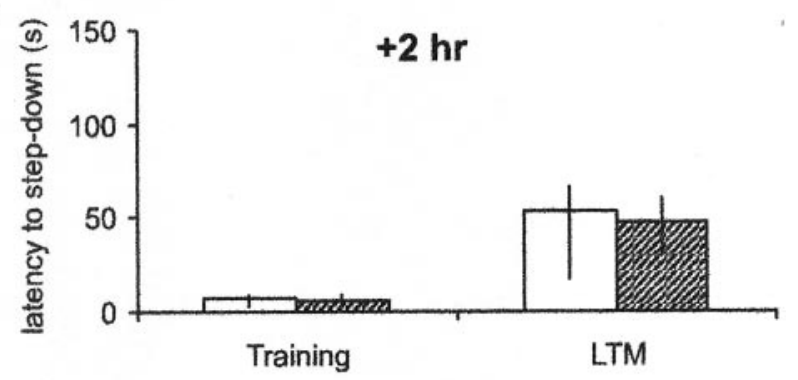

$\mathbf{F}$

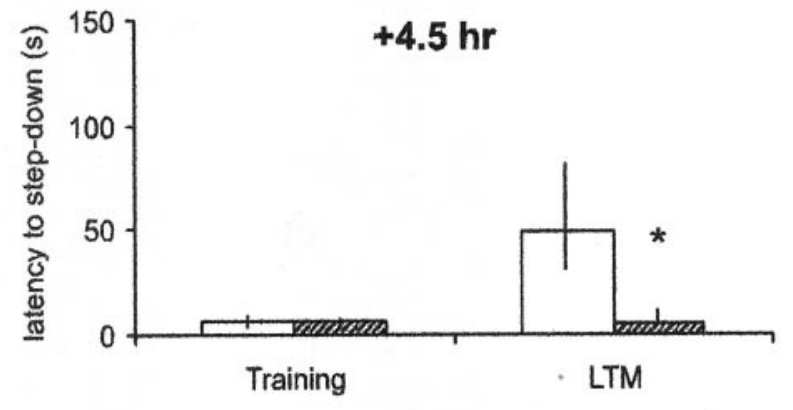

H

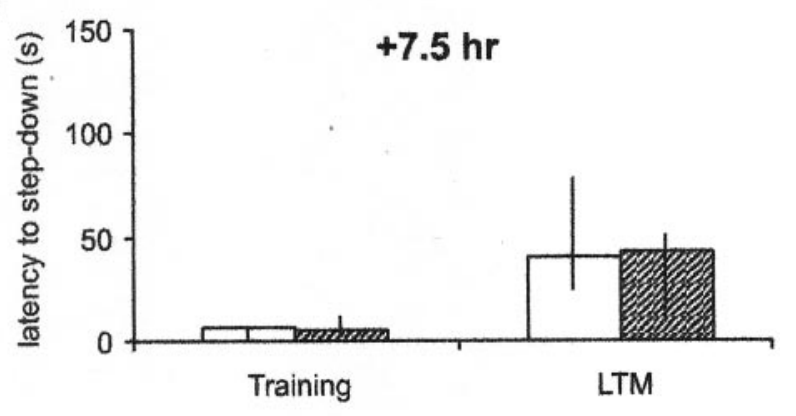

Figure 5. The protein synthesis inhibitor, anisomycin, also reveals two time periods of sensitivity during long-term memory formation of a contextual fear learning. A-I, Anisomycin $80 \mu \mathrm{g}$ per side (hatched bars) or saline (open bars) was infused into the CA1 region of the dorsal hippocampus at different times before or after training. Data are expressed as median (interquartile range) training and test sessions latencies (in seconds). Retention test session for STM was performed at $1.5 \mathrm{hr}$ after training, whereas that for LTM was performed $24 \mathrm{hr}$ after training. $n=9-11$ animals per group. ${ }^{*} p<0.001$ compared with saline-infused rats (Mann-Whitney $U$ test). 
LTM as their specific inhibitors. However, the pattern of the effects of DRB on memory does not match with those previously reported for various inhibitors for NMDA receptors and protein kinases in this task (Izquierdo and Medina, 1997; Izquierdo and McGaugh, 2000; McGaugh, 2000).

An alternative explanation is based on the fact that STM expression is strictly dependent on the experimental procedure (Menzel, 1979; Walker and Davis, 2000). In this context, it has been shown previously that pretraining inhibition of protein synthesis in the same one-trial avoidance task used here impairs both STM and LTM, depending on the level of foot shock used to punish the response (Quartemain and McEwen, 1970). With a high foot shock, only LTM is impaired, whereas with a low shock (like that used in our study), a significant memory loss occurred at $1 \mathrm{~min}, 5 \mathrm{~min}, 6 \mathrm{hr}$, and $24 \mathrm{hr}$ after training. In other words, no STM or LTM is evident. These findings strongly suggest that STM expression is clearly dependent on whether the training was learned under high or low shock.

What are the molecular mechanisms that mediate the two waves of gene expression? Studies in Aplysia, Drosophila, mice, and rats suggested that the CAMP/PKA signaling pathway is an important transduction cascade for LTM formation. In this context, using a weak contextual fear conditioning in mice, Bourtchuladze et al. (1998) found two time windows sensitive to a PKA inhibitor that closely parallel those observed in anisomycintreated animals. We have also found two time periods during which PKA inhibitors administered into CA1 exert amnesic effect for inhibitory avoidance (Bernabeu et al., 1997; Vianna et al., 1999) and that coincide with two peaks of increased phosphorylation of CREB (Bernabeu et al., 1997). CREB-regulated transcription participates in LTM formation of several associative learning tasks (Bourtchuladze et al., 1994; Yin and Tully, 1996; Guzowski and McGaugh, 1997; Izquierdo and Medina, 1997; Impey et al., 1998; Taubenfeld et al., 1999; Cammarota et al., 2000; McGaugh, 2000). Therefore, these findings suggest that the cAMP-PKA-CREB signaling pathway in the hippocampus is one of a series of molecular components that regulates transcription required for LTM formation.

Given that memory formation recruits a diversity of gene expression-related events, distinct intracellular signaling pathways must be involved (McGaugh, 2000; Kandel, 2001; Routtenberg, 2001; Sweatt, 2001a,b). In this regard, other transcription factors and immediate early genes have been shown to be regulated during activity-dependent synaptic plasticity and memory formation (Kinney and Routtenberg, 1993; Kinney et al., 1996; Meberg et al., 1996; Hegde et al., 1997; Steward et al., 1998; Guzowski et al., 1999, 2000, 2001; Cammarota et al., 2000; Hall et al., 2000; Paratcha et al., 2000; Zhao et al., 2000; Taubenfeld et al., 2001). As a corollary, memory formation in the adult brain seems to require time-dependent processes involving multiple signaling cascades that regulate gene expression in selected, but distributed, neuronal populations.

Which are the gene families that are expressed at these two waves of mRNA synthesis required for long-term memory formation? Are they necessarily different at both time windows? Several interesting possibilities arise in terms of overlapping expression patterns and opposite regulation of the same gene(s) in subsequent stages of the memory consolidation process. Expression profiling experiments using cDNA microarrays are currently in progress to answer some of these questions.

\section{REFERENCES}

Abraham WC, Mason SE, Demmer J, Williams JM, Richarson C, Tate W, Lawlor PA, Dragunow M (1993) Correlation between immediate early gene induction and the persistence of long-term potentiation. Neuroscience 56:717-727.

Agranoff BW, Davis RE, Casola L, Lim R (1967) Actinomycin D blocks formation of memory of shock-avoidance in goldfish. Science 158:1600-1601.

Alonso M, Vianna MRM, Depino AM, Mello e Souza T, Pereira P, Szapiro G, Viola H, Pitossi F, Izquierdo I, Medina JH. (2002) BDNFtriggered events in the rat hippocampus are required for both short and long-term memory formation. Hippocampus 12:551-560.

Bailey CH, Bartsch D, Kandel ER (1996) Toward a molecular definition of long-term memory storage. Proc Natl Acad Sci USA 93:13445-13452.

Barros DM, Izquierdo LA, Mello e Souza T, Ardenghi PG, Pereira P, Medina JH, Izquierdo I (2000) Molecular signalling pathways in the cerebral cortex are required for retrieval of one-trial avoidance learning in rats. Behav Brain Res 114:183-192.

Barzilai A, Kennedy TE, Sweatt JD, Kandel ER (1989) 5-HT modulates protein synthesis and the expression of specific proteins during longterm facilitation in Aplysia sensory neurons. Neuron 2:1577-1586.

Bernabeu R, Bevilaqua L, Ardenghi P, Bromberg E, Schmitz P, Bianchin $\mathrm{M}$, Izquierdo I, Medina JH (1997) Involvement of hippocampal cAMP/cAMP-dependent protein kinase signaling pathways in a late memory consolidation phase of aversively motivated learning in rats. Proc Natl Acad Sci USA 94:7041-7046.

Bourtchuladze R, Frenguelli B, Blendy J, Schutz G, Silva A (1994) Deficient long-term memory in mice with a targeted mutation of the cAMP-responsive element binding protein. Cell 79:59-68.

Bourtchuladze R, Abel T, Berman N, Gordon R, Lapidus K, Kandel ER (1998) Different training procedures recruit either one or two critical periods for contextual memory consolidation, each of which requires protein synthesis and PKA. Learn Mem 5:365-374.

Brink JJ, Davis RE, Agranoff BW (1966) Effects of puromycin, acetoxycycloheximide and actinomycin D on protein synthesis in goldfish brain. J Neurochem 13:889-896.

Cammarota M, Bevilaqua LRM, Ardenghi P, Paratcha G, Levi de Stein M, Izquierdo I, Medina JH (2000) Learning-associated activation of nuclear MAPK, CREB and Elk-1, along with Fos production, in the rat hippocampus after a one-trial avoidance learning: abolition by NMDA receptor blockade. Mol Brain Res 76:36-46.

Chodosh LA, Fire A, Samuels M, Sharp PA (1989) 5,6-dichloro-1 $\beta$-Dribofuranosylbenzimidazole inhibits transcription elongation by RNA polymerase II in vitro. J Biol Chem 264:2250-2257.

Chomczynski P, Sacchi N (1987) Single-step method of RNA isolation by acid guanidium thiocyanate-phenol-chloroform extraction. Anal Biochem 162:156-159.

Clement JD, Wilkinson MF (2000) Rapid induction of nuclear transcripts and inhibition of intron decay in response to the polymerase inhibitor DRB. J Mol Biol 299:1179-1191.

Crow T, Siddiqi V, Dash PK (1997) Long-term enhancement but not short-term in Hermissenda is dependent on mRNA synthesis. Neurobiol Learn Mem 68:343-350.

Davis RE, Bright PJ, Agranoff BW (1965) Effect of ECS and puromycin on memory in fish. J Comp Physiol Psychol 60:162-166.

Davis HP, Squire LR (1984) Protein synthesis and memory: a review. Psychol Bull 96:518-559.

de Mercoyrol L, Job C, Job D (1989) Studies on the inhibition by alpha-amanitin of single-step addition reactions and productive RNA synthesis catalysed by wheat-germ RNA polymerase II. Biochem J 258:165-169.

Emptage NJ, Carew TJ (1993) Long-term synaptic facilitation in the absence of short-term facilitation in Aplysia neurons. Science 262:253-256.

Freeman F, Rose SPR, Sholey A (1995) Two time windows of anisomycin-induced amnesia for passive avoidance training in the dayold chick. Neurobiol Learn Mem 63:291-295.

Gold PE (1986) The use of avoidance training in studies of modulation of memory storage. Behav Neural Biol 46:87-98.

Grecksch G, Matthies M (1980) Two sensitive periods for the amnestic effect of anisomycin. Pharmacol Biochem Behav 13:663-665.

Guzowski JF, McGaugh JL (1997) Antisense oligodeoxynucleotidemediated disruption of hippocampal cAMP response element binding protein levels impairs consolidation of memory for water maze training. Proc Natl Acad Sci USA 94:2693-2698.

Guzowski JF, McNaugthon BL, Barnes CA, Worley PF (1999) Environment-specific expression of the immediate-early gene Arc in hippocampal neuronal ensembles. Nat Neurosci 2:1120-1124.

Guzowski JF, Lyford GL, Stevenson GD, Houston FP, McGaugh JL, Worley PF, Barnes CA (2000) Inhibition of activity-dependent ARC protein expression in the rat hippocampus impairs the maintenance of long-term potentiation and the consolidation of long-term memory. J Neurosci 20:3993-4001.

Guzowski JF, Setlow B, Wagner EK, McGaugh JL (2001) Experience- 
dependent gene expression in the rat hippocampus after spatial learning: a comparison of the immediate-early genes Arc, c-fos, and zif268. J Neurosci 21:5089-5098.

Hall J, Thomas KL, Everitt BJ (2000) Rapid and selective induction of BDNF expression in the hippocampus during contextual learning. Nat Neurosci 3:533-535

Hegde AN, Inokuchi K, Pei W, Casadio A, Ghirardi M, Chain DG, Martin KC, Kandel ER, Schwartz JH (1997) Ubiquitin C-terminal hydrolase is an immediate-early gene essential for long-term facilitation in Aplysia. Cell 89:115-126.

Impey S, Smith DM, Obrietan K, Donahue R, Wade C, Storm DR (1998) Stimulation of cAMP response element (CRE)-mediated transcription during contextual learning. Nat Neurosci 1:595-601.

Izquierdo I, McGaugh JL (2000) Behavioural pharmacology and its contribution to the molecular basis of memory consolidation. Behav Pharmacol 11:517-534.

Izquierdo I, Medina JH (1997) Memory formation: the sequence of biochemical events in the hippocampus and its connection to activity in other brain structures. Neurobiol Learn Mem 68:285-316.

Izquierdo I, Barros DM, Izquierdo L, Mello e Souza T, Souza M, Medina JH (1998) Mechanisms for memory types differ. Nature 393:635-636.

Kandel ER (2001) The molecular biology of memory storage: a dialogue between genes and synapses. Science 294:1030-1038.

Kedinger C, Gniazdowski M, Mandel Jr JL, Gissinger F, Chambon P (1970) Alpha-amanitin: a specific inhibitor of one of two DNApendent RNA polymerase activities from calf thymus. Biochem Biophys Res Commun 38:165-171.

Kinney W, Routtenberg A (1993) Brief exposure to a novel environment enhances binding of hippocampal transcription factors to their DNA recognition elements. Mol Brain Res 20:147-152.

Kinney WR, McNamara RK, Valcourt A, Routtenberg A (1996) Prolonged alteration in E-box binding after a single systemic kainate injection: potential relation to F1/GAP-43 gene expression. Mol Brain Res 38:25-36.

Krichevsky AM, Kosik KS (2001) Neuronal RNA granules: a link between RNA localization and stimulation-dependent translation. Neuron 32:683-696.

Lieberman DN, Mody I (1999) Casein kinase II regulates NMDA channel function in hippocampal neurons. Nat Neurosci 2:125-132.

Lindell TJ, Weinberg F, Morris PW, Roeder RG, Rutter WJ (1970) Specific inhibition of nuclear RNA polymerase II by alpha-amanitin. Science 170:447-449.

Lorenzini CA, Baldi E, Bucherelli C, Sacchetti B, Tassoni G (1996) Role of dorsal hippocampus in acquisition, consolidation and retrieval of rat's passive avoidance response: a tetrodotoxin functional inactivation study. Brain Res 730:32-39.

McGaugh JL (1966) Time-dependent processes in memory storage. Science 153:1351-1359.

McGaugh JL (2000) Memory: a century of consolidation. Science 287:248-251.

Meberg PJ, Kinney WR, Valcourt EG, Routtenberg A (1996) Gene expression of the transcription factor NF-kB in hippocampus: regulation by synaptic activity. Mol Brain Res 38:179-190.

Menzel R (1979) Behavioural access to short-term memory in bees. Nature 281:368-369.

Mesches MH, Bianchin M, McGaugh JL (1996) The effect of intraamygdala infusion of the AMPA receptor antagonist CNQX on retention performance following aversive training. Neurobiol Learn Mem 66:324-330.

Milner B, Squire LR, Kandel ER (1998) Cognitive neuroscience and the study of memory. Neuron 20:445-468.

Montanaro N, Novello F, Stirpe F (1971) Effect of alpha amanitin on ribonucleic acid polymerase II of rat brain nuclei and on retention of avoidance training. Biochem J 125:1087-1090.

Neale JH, Klinger PD, Agranoff BW (1973) Camptothecin blocks memory of conditioned avoidance in the goldfish. Science 179:1243-1246.

Nguyen PV, Abel T, Kandel ER (1994) Requirement of a critical period of transcription for induction of a late phase of LTP. Science 265:1104-1107.

Paratcha G, Furman M, Bevilaqua L, Cammarota M, Vianna M, de Stein ML, Izquierdo I, Medina JH (2000) Involvement of hippocampal PKCbetaI isoform in the early phase of memory formation of an inhibitory avoidance learning. Brain Res 855:199-205.

Paxinos G, Watson C (1986) The rat brain in stereotaxic coordinates. San Diego: Academic.

Pedreira ME, Dimant B, Maldonado H (1996) Inhibitors of protein and RNA synthesis block context memory and long-term habituation in the crab Chasmagnathus. Pharmacol Biochem Behav 54:611-617.

Quartemain D, McEwen BS (1970) Temporal characteristics of amnesia induced by protein synthesis inhibitor: determination by shock level. Nature 228:677-678.

Quevedo J, Vianna MRM, Roesler R, de Paris F, Izquierdo I, Rose SPR (1999) Two time windows of anisomycin-induced amnesia for inhibi- tory avoidance training in rats: protection from amnesia by pretraining but not pre-exposure to the task apparatus. Learn Mem 6:600-607.

Rainbow TC (1979) Role of RNA and protein synthesis in memory formation. Neurochem Res 4:297-312.

Rose SP (1995) Glycoproteins and memory formation. Behav Brain Res 66:73-78.

Routtenberg A (2001) It's about time. In: Memory consolidation (Gold PE, Greenough WT, eds), pp 17-34. Washington, D.C.: American Psychological Association.

Squire LR, Barondes S (1970) Actinomycin-D: effects on memory at different times after training. Nature 225:649-650.

Steward O (1997) mRNA localization in neurons: a multipurpose mechanism. Neuron 18:9-12.

Steward O, Wallace CS, Lyford GL, Worley PF (1998) Synaptic activation causes the mRNA for the IEG Arc to localize selectively near activated postsynaptic sites on dendrites. Neuron 21:741-751.

Strocchi P, Montanaro N, Dall'olio R (1977) Effect of alpha-amanitin on brain RNA and protein synthesis and on retention of avoidance conditioning. Pharmacol Biochem Behav 6:433-437.

Sweatt JD (2001a) The neuronal MAP kinase cascade: a biochemical signal integration system subserving synaptic plasticity and memory. J Neurochem 76:1-10.

Sweatt JD (2001b) Protooncogenes subserve memory formation in the adult CNS. Neuron 31:671-674.

Szapiro G, Izquierdo LA, Alonso M, Barros D, Paratcha G, Ardenghi P, Pereira P, Medina JH, Izquierdo I (2000) Participation of hippocampal metabotropic receptors, protein kinase $\mathrm{A}$ and mitogen-activated protein kinases in memory retrieval. Neuroscience 99:1-5.

Tamm I (1977) Definition of subclasses of nucleoplasmic RNA. Proc Natl Acad Sci USA 76:5750-5754.

Taubenfeld SM, Wiig KA, Bear MF, Alberini CM (1999) A molecular correlate of memory and amnesia in the hippocampus. Nat Neurosc 2:309-310.

Taubenfeld SM, Milekic MH, Monti B, Alberini CM (2001) The consolidation of new but not reactivated memory requires hippocampal C/EBPbeta. Nat Neurosci 4:813-818.

Theas S, De Laurentiis A, Candolfi M, Lopez SL, Carrasco AE, Zaldivar V, Seilicovich A (2001) Nitric oxide mediates the inhibitory effect of tumor necrosis factor-alpha on prolactin release. Neuroendocrinology 74:82-86.

Thompson R (1977) Localization of a "passive avoidance memory system" in the white rat. Physiol Psychol 6:263-274.

Thut PD, Lindell TJ (1974) Alpha-amanitin inhibition of mouse brain from II ribonucleic acid polymerase and passive avoidance retention. Mol Pharmacol 10:1146-1154.

Tiunova AA, Anokhin KV, Rose SP (1998) Two critical periods of protein and glycoprotein synthesis in memory consolidation for visual categorization learning in chicks. Learn Mem 4:401-410.

Vianna MRM, Izquierdo LA, Barros DM, Medina JH, Izquierdo I (1999) Intrahippocampal infusion of inhibitor of protein kinase A separates short- from long-term memory. Behav Pharmacol 10:223-227.

Vianna MRM, Szapiro G, McGaugh JL, Medina JH, Izquierdo I (2001) Retrieval of memory for fear-motivated training initiates extinction requiring protein synthesis in the rat hippocampus. Proc Natl Acad Sci USA 98:12251-12254

Walker DL, Davis M (2000) Involvement of NMDA receptors within the amygdala in short- versus long-term memory for fear conditioning as assessed with fear-potentiated startle. Behav Neurosci 114:1019-1033.

Walz R, Roesler R, Quevedo J, Sant'Anna MK, Madruga M, Rodrigues C, Gottfried C, Medina JH, Izquierdo I (2000) Time-dependent impairment of inhibitory avoidance retention in rats by posttraining infusion of a mitogen-activated protein kinase kinase inhibitor into cortical and limbic structures. Neurobiol Learn Mem 73:11-20.

Wetzel W, Ott T, Matthies H (1976) Is actinomycin D suitable for the investigation of memory processes? Pharmacol Biochem Behav 4:515-519.

Winocur G, Bindra D (1976) Effects of additional cues on passive avoidance learning and extinction in rats with hippocampal lesions. Physiol Behav 17:915-920.

Wolfman C, Viola H, Marder M, Wasowski C, Ardenghi P, Izquierdo I, Paladini AC, Medina JH (1996) Anxioselective properties of 6,3' dinitroflavone, a high affinity benzodiazepine receptor ligand. Eur J Pharmacol 318:23-30

Yin JCP, Tully T (1996) CREB and the formation of long-term memory. Curr Opin Neurobiol 6:204-208.

Zandomeni R, Zandomeni MC, Shugar D, Weinmann R (1986) Casein kinase type II is involved in the inhibition by 5,6-dichloro-1-beta-Dibof uranosyl-benzimidazole of specific RNA polymerase II transcription. J Biol Chem 261:3414-3419.

Zhao W, Meiri N, Xu H, Cavallaro S, Quattrone A, Zhang L, Alkon DL (2000) Spatial learning induced changes in expression of the ryanodine type II receptor in the rat hippocampus. FASEB J 14:290-300. 